\title{
Human anti-DNA antibody: reference standards for diagnosis and management of systemic lupus erythematosus
}

\author{
J. HOLIAN,* I. D. GRIFFITHS, D. N. GLASS, R. N. MAINI, AND J. T. SCOTT \\ From The Kennedy Institute of Rheumatology, London, and The Radiochemical Centre, Amersham, Bucks.*
}

\begin{abstract}
Holian, J., Griffiths, I. D., Glass, D. N., Maini, R. N., and Scott, J. T. (1975). Annals of the Rheumatic Diseases, 34, 438-443. Human anti-DNA antibody: reference standards for diagnosis and management of systemic lupus erythematosus. A technique for the measurement of DNA binding activity of sera is described which uses primary internal reference standards in a Farr assay. This allows the DNA binding activity of test sera to be measured in relation to the reference standards and the results are expressed as units $/ \mathrm{ml}$. The use of this standardized assay has led to diminished interassay variation and close interlaboratory correlation, and has provided a clinically useful test. In a survey using the standardized assay, normal sera were found to have binding activity which did not exceed 15 units $/ \mathrm{ml} ; 71 \%$ of patients with systemic lupus erythematosus (SLE) had levels greater than 25 units $/ \mathrm{ml}$; while only $8 \%$ of patients with diseases other than SLE had levels above 25 units $/ \mathrm{ml}$. Values between 15 and 25 units $/ \mathrm{ml}$ appeared to have little diagnostic significance.
\end{abstract}

Raised serum levels of antibodies to double-stranded DNA are reported to occur with a high degree of specificity in systemic lupus erythematosus (SLE) (Robbins, Holman, Deicher, and Kunkel, 1957; Seligman, 1957; Cepellini, Polli, and Celade, 1957; Deicher, Holman, and Kunkel, 1959; Pincus, Schur, Rose, Decker, and Talal, 1969). High levels are associated with disease activity, and rising levels may precede clinical exacerbation (Schur and Sandson, 1968; Hughes, 1971). Measurement of these antibodies by the Farr technique (Farr, 1958; Wold, Young, Tan, and Farr, 1968), which employs $50 \%$ saturated ammonium sulphate to precipitate antibody bound to radiolabelled DNA, has been extensively used because of its sensitivity compared with other methods (Pincus and others, 1969; Carr, Koffler, Agnello, and Kunkel, 1969; Cohen, Hughes, Noel, and Christian, 1971a). Results are expressed in terms of percentage radioactivity precipitated, and interpretation of the measurement depends on previous results of relevant control groups, such as normal healthy individuals; a discriminant level can thus be set corresponding to the 'upper' limit. The disadvantage of this technique is the variability between assays resulting from changes in the nature, age, and con- centration of the radiolabelled DNA and in the reaction conditions (Pincus, 1971), the effect of such variations being reflected in the different ranges of 'normal values' reported (Rochmis, Palefsky, Becker, Roth, and Zvaifler, 1974; Hughes, 1973; Hasselbacher and Leroy, 1974). Results obtained in different laboratories cannot therefore be directly compared and the usefulness of the test, both for diagnostic purposes and for following the course of a patient's antibody levels, is adversely affected.

A new approach has been designed to overcome these difficulties and to allow highly precise measurement of DNA binding in a standardized Farr assay. By expressing the results on a linear scale in terms of serum DNA-binding activity, it has been possible to state a more realistic range of values in health and disease and to evaluate the occurrence and clinical significance of antibodies to DNA.

\section{Methods}

125 I-LABELLED DNA

HeLa cell monolayers are incubated in a growth medium containing ${ }^{125}$ I-iododeoxyuridine. After a suitable period the cells are lysed with $1 \%$ sodium lauryl sulphate solution and the DNA extracted and purified according to the 
method of Marmur (1961). Labelled DNA is obtained with a high specific activity $(>100 \mu \mathrm{Ci} / \mathrm{mg})$ and serum binding values using this preparation show a good correlation with those obtained using ${ }^{14} \mathrm{C}$-labelled DNA derived from HeLa cells and $E$. coli. The ${ }^{125}$ I-labelled DNA preparation yields characteristic ultraviolet absorption spectrum with a ratio of readings at $260 \mathrm{~nm}: 280 \mathrm{~nm}$ of $1 \cdot 85$. Further tests for antigen purity are not performed, and unlabelled RNA is not removed. Stock solutions of ${ }^{125} \mathrm{I}$-labelled DNA are diluted according to the measured optical density at $260 \mathrm{~nm}$ to give a concentration of approximately $0.05 \mu \mathrm{g}$ DNA per assay.

\section{PRINCIPLE OF STANDARDIZED ASSAY}

The method depends on the choice of a representative serum from a patient with SLE as a primary reference standard. DNA binding values of 'unknown' sera are expressed in relation to a dilution curve of the DNA binding activity of the reference standard performed in the same assay. Serial doubling-dilutions of the primary standard are chosen to cover the steep portion of the dilution curve (Fig. 1). A linear scale is obtained by the substitution of arbitrary concentration units for the serum dilution factors as shown in Fig. 1. Thus an arbitrary numerical value of $100 \mathrm{units} / \mathrm{ml}$ is assigned to initial dilution of the primary standard, and the values of the three serial dilutions are then 50,25 , and 12.5 units $/ \mathrm{ml}$, respectively. Similarly, a representative 'normal' standard serum is selected and assigned an arbitrary 0 units $/ \mathrm{ml}$. These standards are dispensed in aliquots and stored as freeze-dried solids. Thereafter secondary reference standards are prepared from other suitable SLE sera and calibrated against the primary standard.

The radioactivity (cpm) of the half-saturated ammonium sulphate precipitates of the reference standard solutions are plotted on the ordinate against their unit values on the abscissa, and a curve is drawn. In Fig. 1 an unknown serum in the test gave a radioactive precipitate of $17000 \mathrm{cpm}$ which, read from the standard curve, corresponds to 40 units/ml of DNA binding activity. In cases in

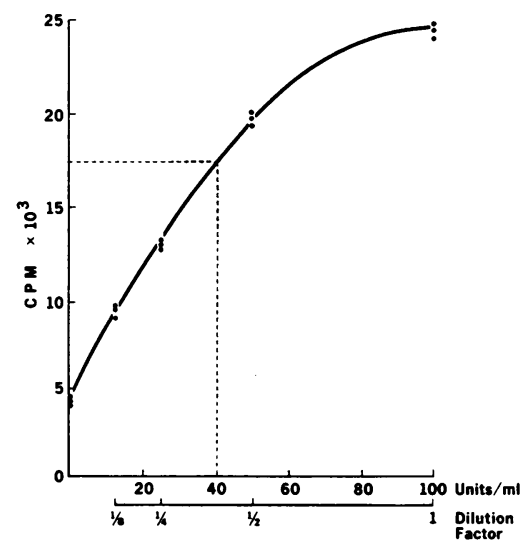

FIG. 1 DNA binding capacity (cpm) of the standard reagents used to obtain a reference curve. (Broken line shows the cpm of a test serum used as an example with its corresponding value of DNA binding activity in units $/ \mathrm{ml}$ ) which the 'unknown' serum precipitate radioactivity exceeds that of the 100 units/ml standard, serial doublingdilutions of the 'unknown' serum are performed in a subsequent test, until a value within the working range is obtained. This value is then corrected for the dilution factor.

\section{PROCEDURE}

The five solutions derived from the standard sera, previously calibrated, are made up in $10 \%(\mathrm{v} / \mathrm{v})$ normal serum concentration in $0.15 \mathrm{~mol} / 1 \mathrm{NaCl}$-borate buffer and are stored in a lyophilized state. For use in the test the standards are reconstituted with distilled water to their original volume with the precaution providing for a larger volume of 'zero' standard, as this reagent is also used for dilution of any 'test' sera previously shown to have $>100$ units/ml DNA binding activity.

The 'test' sera whose DNA binding activity is being assessed are diluted $1 / 10$ in $0.15 \mathrm{~mol} / \mathrm{l} \mathrm{NaCl}$-borate buffer. $50 \mu \mathrm{l}$ of the standard reagents and 'test' sera solutions are incubated at $56^{\circ} \mathrm{C}$ for $30 \mathrm{~min}$ to inactivate serum complement, and then incubated with $50 \mu \mathrm{l}^{125} \mathrm{I}$-labelled DNA solutions at $37^{\circ}$ for one hour. The incubation mixture is then allowed to stand for $16-20$ hours at $4^{\circ} \mathrm{C}$ before the addition of $100 \mu$ l saturated ammonium sulphate solution to precipitate the antigen-antibody complexes. The mixtures are immediately vortexed and centrifuged at $1000 \mathrm{~g}$ for $15 \mathrm{~min}$, the entire supernatant liquid aspirated, and the ${ }^{125}$ I radioactivity of the precipitate measured in a gamma-counter. Tests are carried out in duplicate.

\section{CHOICE OF PRIMARY STANDARDS}

The selection of a primary standard SLE serum requires that it should be representative of other sera in its binding characteristics. Fig. 2 shows the results of an experiment on 11 sera examined. Each serum was serially diluted in the same normal serum to maintain the serum concentration constant throughout, and its DNA binding value measured. The slopes shown in Fig. 2. appear to be similar, but when the data obtained by performing dilution curves on a total of 20 SLE sera were linearized by using a logit response versus log-dose relationship it was found that the slopes of only 9 out of 20 sera tested fell within $2 \mathrm{SD}$ of the slope of the serum chosen as the reference standard. However, the dilution curves of all sera were sufficiently similar to allow the selection of a 'typical' SLE-serum as a primary standard. The ${ }^{125}$ I-DNA binding of 167 sera from healthy individuals was measured, and those sera whose DNA binding values fell in the median range of a distribution curve were pooled and designated the 0 units $/ \mathrm{ml}$ standard.

SELECTION OF SERA FOR INTERASSAY AND INTERLABORATORY VARIATION

Interassay variation was assessed on 3 lyophilized sera, 1 from a normal subject and 2 from patients with SLE. Sera were chosen for this study with binding values in the 'high' normal and the 'low to intermediate' raised levels. Each serum was assayed on 28 different occasions over a 3-month period using eight different ${ }^{125}$ I-DNA preparations. Results were expressed as percentage binding of DNA and in units $/ \mathrm{ml}$ in the standardized test.

Interlaboratory variation was assessed between two 


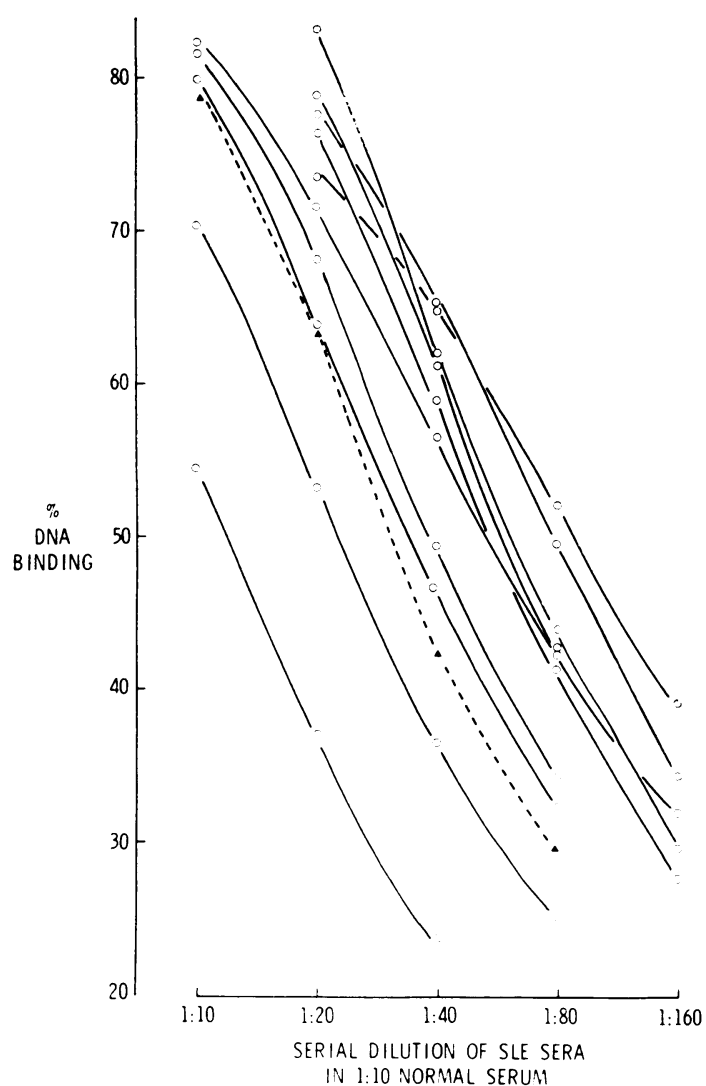

FIG. 2 Serial dilution curves of 11 SLE sera with raised DNA binding. (Broken line represents serum chosen as the primary standard)

laboratories in a double-blind study on samples of 58 freeze-dried sera. 33 of these sera were from patients with SLE, the remainder from patients with rheumatoid arthritis or miscellaneous connective tissue disorders. The DNA binding activity ranged between 0 units $/ \mathrm{ml}$ and 1200 units/ml.

\section{SUBJECTS STUDIED}

Sera from 167 subjects in the age range 18-60 years, in apparently good health, were used as healthy controls. 42 patients with SLE (aged 17-65) fulfilling at least 4 ARA criteria (Cohen, Reynolds, Franklin, Kulka, Ropes, Shulman, and Wallace, 1971b) were studied and disease activity was assessed by the usual clinical criteria. 32 hospital inpatients, age range $15-80$ years, who had no evidence of any autoimmune disease were used as an additional control population. The following 114 patients were also examined: rheumatoid arthritis (26), rheumatoid arthritis with antinuclear antibodies and/or LE cells (24), rheumatoid arthritis complicated by vasculitis and/or fibrosing alveolitis (11), miscellaneous group comprising scleroderma, polymyositis, and arteritis, usually with antinuclear antibodies (22), Sjøgren's syndrome with rheumatoid-type arthritis (14), and chronic active hepatitis (17).

\section{Results}

The results of interassay variation comparing values in the standardized assay with those obtained when the results were expressed as percentage DNA bound in the same assay are shown in Fig. 3. Using the standardized assay the interassay variation was considerably less than that obtained for values expressed as percentage DNA bound. Thus with the standardized assay the mean values $( \pm \mathrm{SD})$ obtained for sera $A, B$, and $C$ were $41 \pm 2 \cdot 9,25 \pm 2 \cdot 2,6 \pm 3 \cdot 5$ units/ml compared with percentage DNA binding values $( \pm$ SD) of $49 \pm 10 \cdot 5,36 \pm 9 \cdot 2$, and $18 \pm 5 \cdot 9$, respectively. Furthermore, there was a considerable overlap in the range of values among the three sera when expressed in terms of percentage DNA binding, with each serum showing binding between 30 and $40 \%$ at some point, thus making precise interpretation of any single result difficult. This problem did not occur using the standardized assay system where the antibody activity of the three sera was clearly separated throughout.

Interlaboratory measurement of the 58 freeze-dried serum samples assayed gave a correlation coefficient $(r)$ of $0.982(\mathrm{P}<0.001)$ (Fig. 4). A binding value of 25 units $/ \mathrm{ml}$ appears to have clinically discriminating significance (see below), and if this value is used on one serum gave a binding value which was great than 25 units $/ \mathrm{ml}$ in one laboratory and less in the other (30 units $/ \mathrm{ml}$ and 22 units $/ \mathrm{ml}$, respectively).

A normal range was established by measuring the DNA antibody activity of healthy controls. These were measured in batches in 5 separate assays and the highest value recorded was 15 units $/ \mathrm{ml}$, while more than $95 \%$ of the sera tested had values of less than 10 units $/ \mathrm{ml}$. 36 out of 42 SLE sera $(86 \%)$ had DNA binding activity in excess of 15 units $/ \mathrm{ml}$.

Examination of sera from hospital controls and other disease categories is shown in Fig. 5. It will be observed that in these categories several sera gave a binding value greater than 15 units $/ \mathrm{ml}$, but only rarely was the value of 25 units $/ \mathrm{ml}$ exceeded ( 12 out of $146: 8 \cdot 2 \%$ ). On the basis of this observation the results of binding in the SLE patients were re-evaluated. Thirty out of 42 SLE sera had more than 25 units $/ \mathrm{ml}$ of activity $(71 \%)$. Of 24 patients with active SLE, $22(92 \%)$ showed levels greater than 25 units $/ \mathrm{ml}$. These results indicate that healthy normal sera do not appear to have DNA binding activity in excess of 15 units $/ \mathrm{ml}$, while levels between 15 and 25 units $/ \mathrm{ml}$ are frequently present in a wide spectrum of diseases other than SLE and are of little diagnostic value. Levels greater than 25 units/ml are largely confined to SLE sera.

Among the other disease categories, DNA binding in excess of 25 units $/ \mathrm{ml}$ was detected in 3 out of 14 sera from patients with Sjøgren's syndrome and 2 out of 17 sera from patients with chronic active hepatitis. 


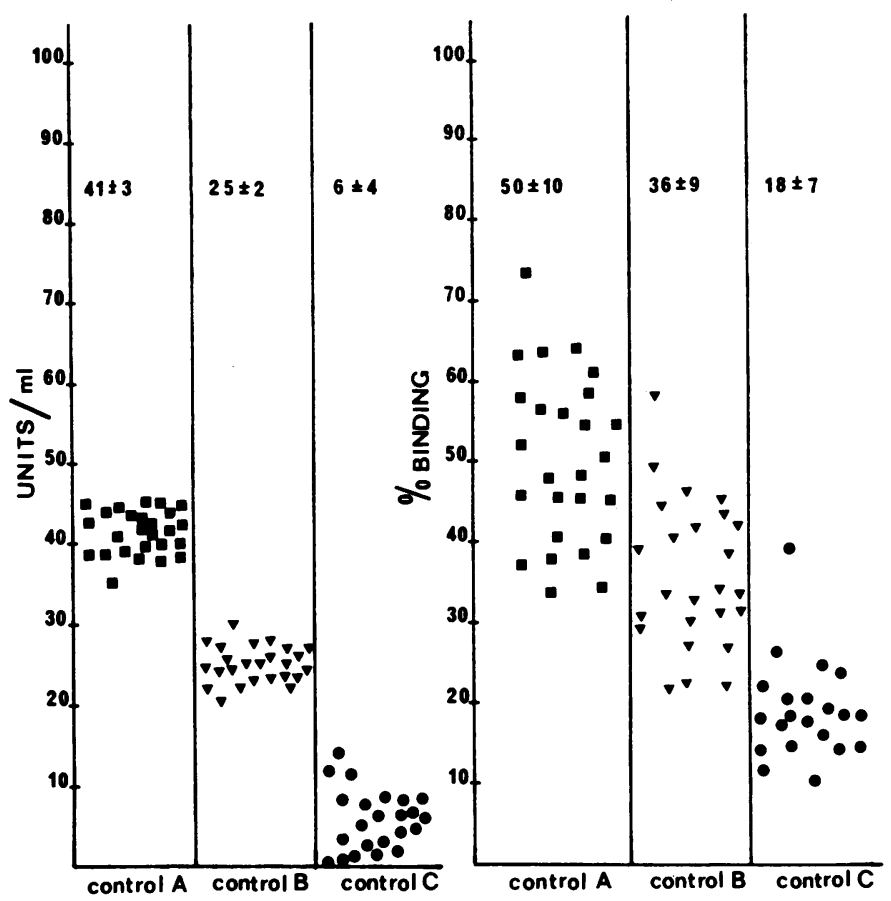

FIG. 3 Interassay variation on $3 \operatorname{sera} A, B$, and $C$ with mean $\pm S D$ (Each point represents mean of duplicate values of a single assay). Results are expressed as (a) units/ml DNA binding activity using standard assay; (b) \% $D N A$ binding in the same assay

$\mathbf{a}$

b

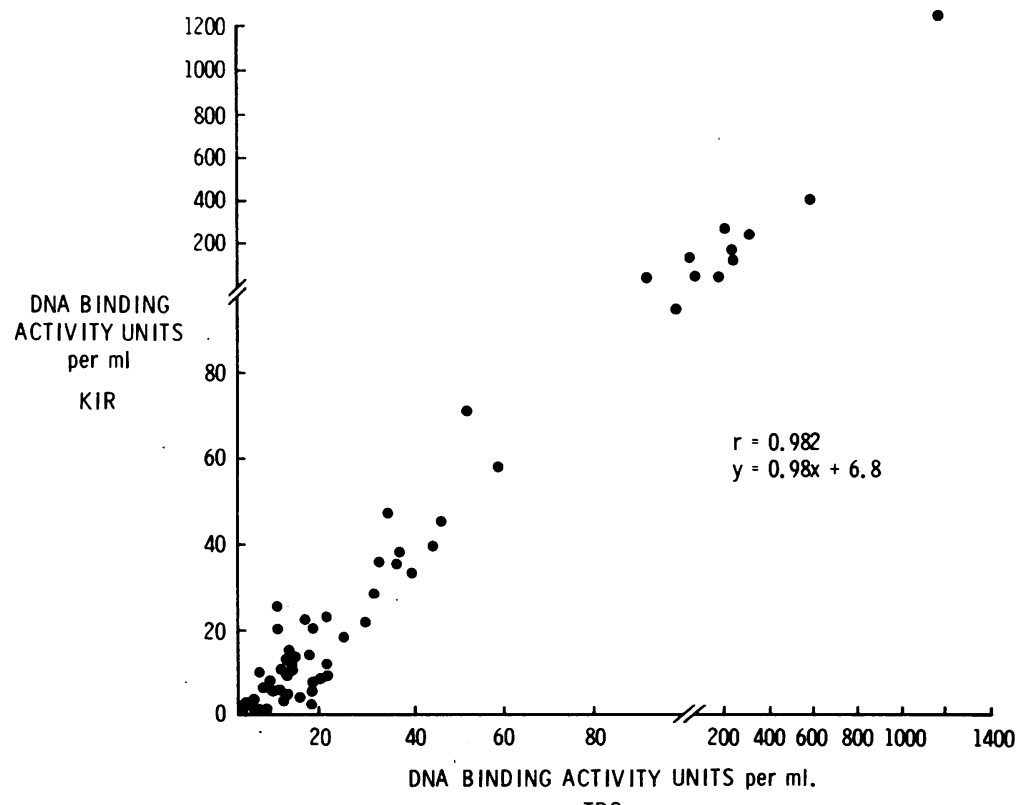

FIG. 4 Interlaboratory (KIR and $T R C)$ correlation of $D N A$ binding activity measured by the standardized assay of 58 sera in a double-blind study 


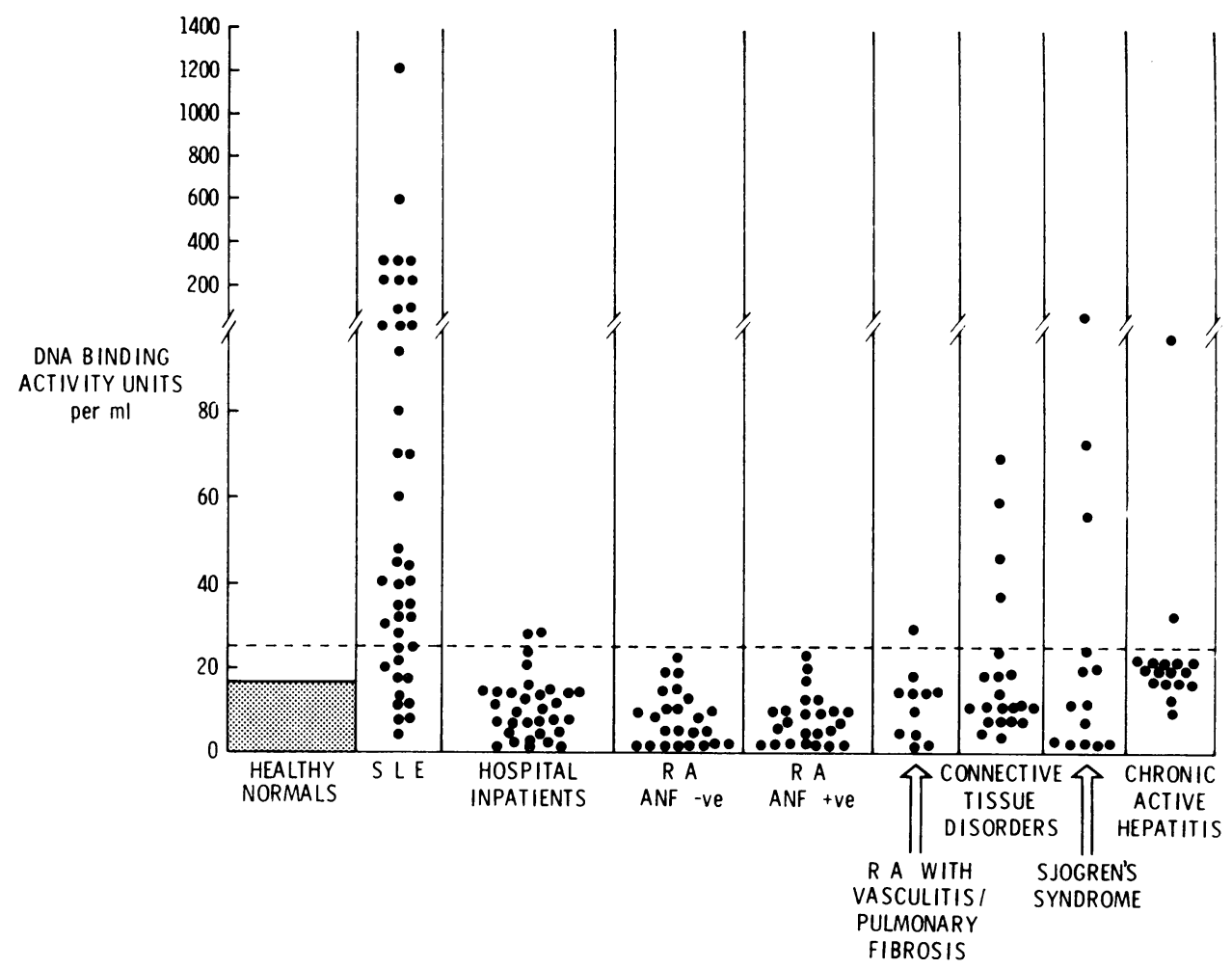

FIG. 5 DNA binding activity as measured in the standardized assay in various disease categories. Range of healthy norma? values was estimated on 167 sera. (Broken line represents possible upper discriminatory level for diagnostic purposes)

Five other patients diagnosed as persistent vasculitic ulcer of unknown aetiology, primary biliary cirrhosis with scleroderma, erythema multiforme, dermatomyositis with features of scleroderma, and rheumatoid arthritis with extensive vasculitis also had levels greater than 25 units $/ \mathrm{ml}$. Two inpatients had levels of 29 and 30 units $/ \mathrm{ml}$, both of whom had terminal carcinoma.

\section{Discussion}

The standardized assay for measurement of antiDNA antibodies described in this paper uses generally accepted methods in which the assay control reagents are used in each assay to obtain a calibration curve which is employed as a reference for measuring the binding activity of sera under investigation. All assay solutions, including standards and unknowns, are prepared at a serum dilution of $1: 10$ to ensure that, as far as possible, the reaction medium is maintained constant and to minimize any nonspecific effects due to the presence of serum. It will be noted that the 'zero control' serum which establishes the 0 unit of activity in our assay does in fact bind DNA but establishes a scale which is of both diagnostic and clinical value.
Although the nature of the binding molecules in normal individuals is controversial, at least one group of workers has claimed that it is partly due to specific anti-DNA antibody (Hasselbacher and Leroy, 1974).

The validity of selecting a single serum as a reference standard for the purposes of measuring antibody concentration in other sera rests on the assumption that the test sera have similar dilution characteristics to the standard. In fact the SLE sera tested did not all have dilution curves identical to the reference standard and, for this reason, it should not be assumed that the test provides an absolute measure of the antiDNA antibody concentration in any single serum. Such criticisms, however, are applicable to all primary binding assays, regardless of the method of expressing the results. Clearly, the major advantage of this present assay lies in its high degree of interassay reproducibility, allowing a fixed 'normal range' to be stated with greater confidence. Thus, using repeated assays and examining a larger number of healthy individuals, the upper limit of binding activity did not exceed 15 units $/ \mathrm{ml}$. In contrast, patients with SLE showed levels above 25 units $/ \mathrm{ml}$ in nearly three-quarters of the cases and there was a close association with disease activity. 
It was of interest to examine the sera of patients with a variety of autoimmune disease other than SLE for antibodies to DNA, for it is in this context that the specificity of this test is most apparent. It appears that a number of patients with rheumatoid arthritis and other autoimmune diseases, as well as the inpatient controls, have values which are somewhat higher than those of healthy individuals. However, the degree of specificity for a diagnosis of SLE became apparent in patients whose binding values exceeded 25 units $/ \mathrm{ml}$, but this was not invariable since twelve patients with diseases such as Sjøgren's syndrome, chronic active hepatitis, polymyositis, erythema multiforme, and two patients with terminal carcinoma also showed levels above 25 units $/ \mathrm{ml}$. Patients within some of these categories have been previously noted to have raised DNA binding (Pincus and others, 1969).

Conversely, the presence of DNA binding is not essential for a diagnosis of SLE, since several patients whose clinical status satisfied this diagnosis, including two who had observable disease activity, did not have binding levels above 25 units $/ \mathrm{ml}$.

It is of interest that thirteen of fourteen SLE patients with renal disease (defined by proteinuria $>1$ g daily or creatinine clearance $<70 \mathrm{ml} / \mathrm{min}$ ) showed DNA binding greater than 25 units $/ \mathrm{ml}$ at some stage of their disease. There was also a significant inverse correlation between DNA binding activity and C3 complement levels in 28 SLE sera examined $(r=0.6$; $P<0.001)$. Thus, in general, the assay tended to be positive when there was renal involvement, in agreement with other studies (Schur and Sandson, 1968), but raised levels, sometimes with values above 1000 units/ml, occurred in a number of patients without functional renal impairment.

The low levels of binding (0-25) units/ml obtained in normals and non-SLE syndromes may have been the result of using uncharacterized antigen which was not all pure double-stranded DNA and further experiments with highly purified and physically defined polynucleotide antigens may be desirable. Nevertheless, our clinical experience suggests that our antigen preparation produces valid clinical results. Indeed the approach for estimation of antiDNA antibodies could be used for other defined antigens, allowing better comparisons to be made between the results obtained in different laboratories.

We thank Miss Patricia Mumford and Mrs. M. A. Stobie for excellent technical assistance, the Clinical Research Committee of Charing Cross, and the Arthritis and Rheumatism Council for their financial support, and Dr. E. J. Holborow for helpful discussion.

\section{References}

Carr, R. I., Koffler, D., Agnello, V., and Kunkel, H. G. (1969) Clin. exp. Immunol., 4, 527 (Studies on DNA antibodies labelled with actinomycin-D (3H) or dimethyl $(3 \mathrm{H})$ sulphate)

Cepellini, R., Polli, E., and Celade, F. (1957) Proc. Soc. exp. Biol., 96, 572 (DNA reacting factor in serum of a patient with lupus erythematosus diffusus)

Cohen, S. A., Hughes, G. R. V., Noel, G. L., ANd Christian, C. L. (1971a) Clin. exp. Immunol., 8, 551 (Character of anti-DNA antibodies in systemic lupus erythematosus)

Cohen, A. S., Reynolds, W. E. Franklin, E. C., Kulka, P. J., Ropes, M. W., Shulman, L. E., and Wallace, S. E. (1971b) Bull. rheum. Dis., 21, 643 (Preliminary criteria for the classification of systemic lupus erythematosus)

Deicher, H. R. G., Holman, H. R., AND Kunkel, H. G. (1959) J. exp. Med., 109, 97 (The precipitin reaction between DNA and a serum factor in systemic lupus erythematosus)

FARR, R. S. (1958) J. infect. Dis., 103, 239 (A quantitative immunochemical measure of the primary interaction between I* BSA and antibody)

Hasselbacher, P., AND Leroy, E. C. (1974) Arthr. and Rheum., 17, 63 (Serum DNA binding activity in healthy subjects and in rheumatic diseases)

HugHes, G. R. V. (1971) Lancet, 2, 861 (Significance of anti-DNA antibodies in SLE)

- (1973) Brit. J. Haemat., 25, 409 (Diagnosis of systemic lupus erythematosus)

MARMUR, J. (1961) J. Molec. Biol., 3, 208 (A procedure for the isolation of deoxyribonucleic acid from microorganisms)

Pincus, T. (1971) Arthr. and Rheum., 14, 623 (Immunochemical conditions affecting the measurement of DNA antibodies using ammonium sulphate precipitation)

—-, Schur, P. H., Rose, J. A., Decker, J. L., AND Talal, N. (1969) New Engl. J. Med., 281, 701 (Measurement of serum DNA binding activity in systemic lupus erythematosus)

Robbins, W. C., Holman, H. R., Deicher, H. R., and Kunkel, H. G. (1957) Proc. Soc. exp. Biol., 96, 575 (Complement fixation with cell nuclei and DNA in lupus erythematosus)

Rochmis, P. G., Palefsky, H., Becker, M., Roth, H., AND Zvaifler, N. J. (1974) Ann. rheum. Dis., 33, 357 (Native DNA binding in rheumatoid arthritis)

Schur, P. H., AND SANDSON, J. (1968) New. Engl.J. Med., 278, 533 (Immunological factors and clinical activity in systemic lupus erythematosus)

Seligman, M. (1957) C.R. Soc. Biol., 245, 243 (Evidence in the serum of patients with systemic lupus erythematosus of a substance producing a precipitation reaction with DNA)

Wold, R. T., Young, F. E., TAN, E., AND FARR, R. S. (1968) Science, 161, 806 (Deoxyribonucleic acid antibody; method to detect its primary interaction with deoxyribonucleic acid) 